[McDonald, L. (2005). Teacher Education, Training and Experience: Knowing What, How, When, Why and With. New Zealand Annual Review of Education, 14, 131-151]

\section{Teacher Education, Training and Experience: Knowing What, How, When, Why and With}

\section{LEX MCDONALD}

\section{Abstract:}

Most teacher development programmes emphasise education and experience, the "what" and "how" of teaching. This article hypothesises that training is often overlooked as a powerful component of teacher development, consequently making achievement of expertise more problematic. Training can help the teacher move to higher levels of performance when the "what" and "how" are linked. Furthermore, it is suggested that transfer is a means of cementing this linking of the education, training and experiences of teachers so that on-the-job performance is sustained. Teacher educators need to know "why" some development strategies are used for transfer and, in particular, highlight those that provide understanding and experience "with" others.

$\mathrm{T}$ eacher preparation and education is not a simple activity, and since its conception it has been examined, critiqued and subjected to numerous transformations. Lay viewpoints, political agendas, economic conditions and various theoretical learning-teaching perspectives have contributed to the evolving understanding about what constitutes effective teacher education. Although once regarded as a training endeavour, it has in more recent times been considered as education. Undoubtedly the professionalisation of a teacher is a complex and multifaceted process, but it needs to be guided by an appreciation that teacher development is more than education - it is generated as a product of the relationship between teacher education, training and experience. Furthermore, the notion of an "expert teacher" should be founded upon what we already know about educating adults and ensuring that on-the-job performance is achieved. Teacher
132 Lex McDonald

educators are no different from other educators. In relation to their audience they need to teach "what" and "how", but also know the "when" and "why" of teaching and learning. They also need to arrange contexts of "know-with" in learning for a collegiality of support so that ideas and practices are readily implemented and sustained in practice. It is postulated that the best means of achieving this is to mediate teacher education and experience with training.

\section{The Changing Face of Teacher Education}

In recent times throughout the Western world there has been considerable debate, discussion, research and community comment about teacher quality. But this disquiet about teacher preparation and performance is not new. What is new is a recognition that societal, economic and political contexts modify perspectives, which in turn impact upon the notion of what constitutes a good teacher, and on beliefs about how best to ensure that teacher performance results in high level student performance. At a time when accountability has come more to the fore in education, much of this discussion in New Zealand has centred upon teacher behaviours (e.g., Education Review Office, 1998; Hattie, 2003) bringing into focus questions relating to the adequacy of teacher training (e.g., Larson, 2005; Education and Science Committee, 2004) and classroom teaching methodologies (e.g., Alton-Lee, 2003). These discussions are mirrored by overseas research and reports (e.g., Wilson \& Floden, 2003). This is not, however, a simple issue. Anecdotal reporting may nurture issues, while still remaining speculative; expert teachers in one context may not be in another; and, as Cochran-Smith (2004) notes, research findings are at times bewildering and seemingly contradictory. However, amongst the morass of speculations, research findings, reports, and commissions there are recurring issues relating to teacher preparation and professional development that require careful scrutiny. This article considers one such issue - the importance of recognising training as a component part of teacher preparation and on-going professional development.

The emphasis in teacher preparation and professional development has changed over the years, in response to the prevailing views of what constitutes the teaching-learning process, although old issues resurface as new ones in changed social and economic climates (Cochran-Smith, 2003). From the 1960s to the 1980s emphasis was upon the identification of effective teaching strategies that might result in higher student 
performance. The notion was that teachers should become skilled in using these strategies and therefore better able to meet the needs of their students. This approach was based upon the process-product model, coupled with a technicist notion of teaching. On the whole, the results were somewhat disappointing because, although many effective teaching strategies could be identified, it became apparent that contextual issues played an important part in determining the success of learning outcomes (Thiessen, 2000). The second approach, evolving in the 1980s, grew as a response to the technicist perspective, and emphasised teacher understanding and reflection. The "reflective teacher" became a precept underlying effective teaching. The third, and emerging approach, is somewhat more speculative - it concerns the development of teacher knowledge that explicitly links theory and practice (Thiessen, 2000).

Throughout this progression of ideas, the process of teacher development can be tracked. The technicist approach rested upon a specifically training paradigm whereas the latter approaches have emphasised the importance of teacher education. Indeed it has become very unfashionable to consider teacher preparation and development in terms of a training paradigm. One explanation for this was the belief that training and professionalisation were not easy bed-fellows for some vocations - and yet, paradoxically, many high status professions such as medicine, engineering and legal work involve specific training programmes. It would seem that this paradox can in part be explained by the extent to which the job has a status, deriving from a well-defined body of information, applied knowledge and high level skills.

\section{Education, Training and Experience}

Part of the difficulty, however, is that there has been considerable confusion in the literature about what constitutes education, training and experience (Farquharson, 1995, Glasser, 1962; Gliessman, 1984; Hills, 1982; Reid \& Barrington, 1999). Many assume that training is best defined in terms of the acquisition of lower order physical skills (Cruickshank \& Metcalf, 1994) and regard experience as a life event that simply adds to one's education. It is probably wise to avoid simple definitions, however, and consider them all relatively equal in terms of contributing to learning, but with different emphases. As Reid and Barrington (1997) state, there is overlap in the use of these terms in breadth of content coverage, purposes and methodologies. At university, for example, one can acquire an education as well as training, but neither can assume that knowledge or "savvy" on-the-job is accomplished. Experience can arise from both activities but can also exist outside of them. Hence difficulties can arise when assumptions are made about the nature of education, training and experience. Clarification of the terms becomes a necessity, and it seems realistic to adopt the following interrelated definitions, drawing upon the ideas of Billings (1981), Blanchard and Thacker (2004), Cruickshank and Metcalf (1994), Farquharson (1995), Reid and Barrington (1997) and Robertson (1987). The common element is that learning can occur in all three processes.

Education has a goal of learning, and is the opportunity to focus on more general knowledge, skills and attitudes related to a person's job or care. The emphasis is upon being informed and knowing something and the accumulation of knowledge, skills and attitudes. However, it can act as a catalyst for the development of more practical and applied responses.

Training also has a goal of learning, and is the systematic process of providing an opportunity to learn job-specific knowledge, skills and attitudes for current or future jobs. The emphasis is upon knowing how to do something, the application of the knowledge skills and attitudes, but theory and high level cognitive responses can evolve from such activity.

Experience often results in learning, and this is a consequence of activities (planned or otherwise) that occur in a real-life or simulated contexts via a process of action and reflection. It is learning in-vivo and both education and training can interact meaningfully with learning by experience.

If it is accepted that training has the potential to assist with the professionalisation of teaching why has this opportunity been overlooked? Why are some educators so sceptical and critical about training? Firstly, this was primarily because training per se had, until relatively recently, been atheoretical, its outcomes were regarded as mechanistic, and it was regarded negatively in relation to education. Because of its lack of theoretical integrity and its technicist orientation, a negative mind-set was developed in some circles. This negative viewpoint started to lose traction in the 1990s, however, when training expanded from the somewhat simple utilisation of behavioural practices to a more complex orientation involving cognitive programmatic 
designs (Kraiger, 2001). Secondly, there have only been a relatively limited number of researchers and university staff interested in teacher training and displaying the capacity to develop integrated teacher "know-how" and "know-what" programmes that emphasise on-the-job performance (Cruickshank \& Metcalf, 1994; McDonald, 2001). Thirdly, training has been largely disregarded in the past because it is demanding of time and resources - factors that often preclude its use. This has significant financial, organisational, and teacher educator role implications. Finally, it has been difficult for teacher educators to train student teachers (or other teachers) if they have had little training and education themselves in the theories and practice of training. The reality is that most teacher educators do not have substantial training expertise or experience when they are appointed to their positions.

\section{Professionalisation: Novice to Expert}

An important consideration in this discussion is the relationship of teacher preparedness to teacher professionalisation, and to the progression from novice to expert status. This embodies a notion of the "know-when", as it defines in various ways the stages that teachers proceed through toachieve competency, and highlights the consequent need for educators to programme events and activities for this growth. This cannot however be simply understood as a linear knowledgegaining process (Eraut, 1994). As Thiessen (2000) has noted, the emerging trend in teacher education is the blending of explicit knowledge with teachers' experience. It is postulated that this can be accomplished if a very functional interactive relationship between education, training and the experience is developed. Professionals need to be aware of the significance of theory supplemented by on/off campus training, to allow specific qualities to develop which will be embedded in experience. The blending of theory with experience is at times very problematic (Munby \& Russell, 1996), but can be achieved more readily if training can mediate the two and become a bridge to acquiring knowledge and/or experience. This implies, for example, that a professional can be exposed to theory and this can be understood more clearly when linked to a form of training (simulated or in-vivo), which in turn is followed-up with field experiences. Or, an experience can be made more meaningful when practice and training follows with theory explaining why it occurs in this fashion. Munby and Russell argue that theory followed directly by experience is an inappropriate means of teacher education.
The literature on professionalisation has alluded to this functional, interactive relationship between education, training and experience. Traditionally the acquisition of specialised knowledge and competencies has often been regarded as one of the hallmarks of a profession, but Eraut (1994) describes professionalism in terms of an ideological foundation - service, trustworthiness, integrity, autonomy, and reliable standards - and the knowledge and competencies need to arise from this foundation. However, although the strategies to achieve the competencies and outcomes have been identified (the "know-what"), there is little indication about how such qualities are used on the job. The Dreyfus and Dreyfus (1986) model of skill acquisition, subsequently developed by Berliner (1994), outlined the stages of novice, advanced beginner, competent, proficient, and expert and it was suggested that adults progressively acquire such skills, initially via training and later essentially by experience. Eraut (1994) noted that the training phase was important to allow professionals to acquire the rules (in the early stages) and relate these to the experiences that move them from novice to expert performance.

What about the realisation of exemplary performance by a teacher? This is the end product of the process of professionalisation - but can it be achieved with teacher education and experience, or is training needed as well? There are numerous accounts (e.g., Education Review Office, 1998) of what an effective teacher should be able to accomplish. This centres around a varied range of knowledge, skills and attitudes such as:

- knowing how to assess and evaluate students;

- planning learning events, implementing teaching so that learning occurs;

- analyzing and reflecting on teaching;

- establishing relationships with students and colleagues;

- developing students' positive intrapersonal skills (self concept, self efficacy, etc.)

- problem solving;

- managing classroom behaviour;

- performing administrative skills; and

- development of an educative role for colleagues and pre-service teachers.

These complex demands are obviously associated with highlydeveloped knowledge, skills and attitudes - simply being aware or 
having the "know-what" is insufficient. The "know-how" is also necessary, and teacher educators need to "know-when" to programme these activities, "know-why" to use certain strategies and "know-with" whom they can get support to develop ideas.

There are competing perspectives of course on what constitutes a competent, expert teacher. Some describe teacher professionalisation as a process, whilst others are more prescriptive. Berliner (2001) noted the importance of excellence in the specific domain of teaching, with experts displaying automaticity for repetitive actions, and being more flexible and opportunistic than novices. To him the expert teacher was one who had talent, has capacity to understand, could interpret the context and engage in deliberative practice. Schön's (1987) reflective practitioner approach was also an interpretive process, and was particularly critical of the rational-technicist point of view as being simplistic and unrelated to meaningful practice. He believed that a professional's work was creative, and when problems arose, experience and reflection were used to solve the issues. He postulated three types of reflection. Reflection-on-action refers to reflection on actions and thoughts after the practice, whereas reflection-in-action is reflection about the event and our ways of thinking and acting during this action. The third type, reflection-for-action, is a synthesis of the other two and is a process that encompasses all times - past, present and future. In the view of Schön, the competent professional is one who has the "know-what", but deals with contextual issues via a reflective process. One difficulty, however, was that Schön did not clearly define what he meant by reflection, and neither did he explain how it was to be achieved. Ironically, one of the best means of becoming skilled in reflection is to practice it via training (Chew \& McInnes-Bowers, 2003).

Fenstermacher and Richardson (2000), in discussing the expert teacher, have identified the "good teacher" and the "successful teacher." The former subscribes to Eraut's notion of what constitutes professionalism whilst a successful teacher is determined by the successful learning of the students. Hattie (2003), in a similar vein, demonstrated the relative power of the teacherin student achievement, and suggested that a distinction between the "expert" and "experienced" teacher is more meaningful than the "novice - expert" distinction. He suggested that expert teachers need to be regarded as models for other teachers. Five dimensions of the expert teacher were identified. Expert teachers can more readily:
- identify representations of their subjects;

- guide learning through classroom interactions;

- monitor learning and provide feedback;

- attend to affective attributes; and

- influence student outcomes.

Glaser (1996) described expertise in terms of a change of agency over three interactive phases. The first stage referred to an externally supported environmental structuring, the second transitional stage was characterised by an apprenticeship-type approach, and the third phase was self regulatory, involving individual deliberative action.

Implied in all of these discussions about teacher professionalisation and expert teaching, is the notion that it can be emulated - that is, teachers can become professional expert teachers. Undoubtedly most teacher education programmes provide some practical skill training in these areas, but the emphasis remains upon declarative knowledge with procedural and conditional knowledge being more marginal objectives. The mood in tertiary education is for more accountability and more focussed outcomes, and as teacher education in New Zealand becomes more university-located this has the potential to become more of a problematic issue. Gallagher (2000) discussed the rise of corporate universities in response to dissatisfaction with traditional tertiary programmes that were unable to meet the vocational interests of students, or promote the development of inter-disciplinary skills such as problem solving and team-work. He noted that this is why the OECD recommended apprenticeship models of university education, emphasising tacit procedural knowledge rather than the teaching approach. Even teaching experience does not necessarily provide the expert guidance and coaching necessary - supervising or associate teachers responsible for student-teachers, and tutor teachers supervising new teachers, have little opportunity to learn the necessary skills for inducting and training teachers. What Cruickshank and Metcalf (1994) wrote is still largely true for many student teachers:

Field experiences are more akin, by way of analogy, to swimming preparation, wherein learners are given general conceptual knowledge about the complexities of swimming and the substantial knowledge and practice with each of its elements; or to swimming preparation, wherein, following a description of the general conceptual knowledge (for example they are told to "be clear"), learners are thrown into the pool with the charge, "Now let's see if 
you can do it?" Exhortation to "do it!" seems to take precedence over real training in "here's how to do it." (pp. 118 - 119)

\section{Transfer of Learning and Training}

In the discussions about the centrality of education, training and experience to teacher development and professionalism, there is something that has frequently been overlooked. That is, the process of transfer (managed or haphazardly occurring) by which teachers have embedded knowledge, training and experience into their on-the-job performance. Transfer of learning has manifest implications for the role of teacher educators; indeed it provides an answer to the vexed question of why so many new (and not so new) teachers fail to perform well. It is an over-arching and generic concept, a core process feature of successful training and education activities and future learning (Haskell, 2001). It is also a very complex concept, and there is considerable debate about its theoretical foundation, its nature, how it functions, and the extent to which transfer can occur. McDonald (2005) notes the complexity of transfer of training, and this becomes apparent when it is understood that it is intertwined with many other complex educational issues, such as change, adult learning, instructional design, professional development practices and the socio-cultural milieu. Nevertheless, the weight of the evidence is that purposeful transfer can be made to happen. Haskell (2001) believes this can best be achieved if the haphazard use of strategies is avoided and a more principled approach is adopted, based upon what is known about learning. He believes it is crucial for educators to "know-why" certain strategies and approaches to transfer are used if sustained on-the-job implementation is to be accomplished.

In the past 15-20 years there has been increased interest in the concept of transfer in education, business and industry for a number of reasons, one being the growing concern that training does not inevitably result in on-the-job implementation. Although outcome data measuring transfer are difficult to compare, this is a concern, because there are many reports of the millions of dollars spent on training with, at times, minimal implementation of ideas. Brinkerhoff and Gill (1994) suggested, for example, that 80 percent of training efforts are not implemented, whilst Broad's (1997) research indicated that 60 percent of programmes were not being implemented after training.

Many adopt the position that transfer of training (which has occurred when an individual applies in the work-setting the knowledge, skills and attitudes learnt in a training context) is a subset of transfer of learning (which refers to the application of any new learning in any new setting) (Haskell, 2001). Transfer of learning has occurred, for example, when an individual uses the knowledge and skills learned in one computer software programme (e.g., Excel) for another programme (e.g., Access). This learning has not necessarily been the result of an intentional formal training activity. When a teacher applies a new teaching technique in the classroom, based upon information and skills gained via an in-service course, transfer of training has occurred.

A significant development relating to transfer of training occurred in the late 1980s with the creation of the first complex and sophisticated model of the transfer process (see Figure 1). This model of Baldwin and Ford (1988) highlighted the importance of transfer, and detailed how the training programme, trainee and work environment were key determinants in ensuring on-the-job implementation. Since this time there have been numerous adaptations of the model, reports and research studies discussing transfer.

There are a growing number of researchers and commentators in education (Kurtts \& Levin, 2000; McDonald, 2001; Perkins, Barell \& Fogarty, 1989; Rhodes \& Beneicke, 2003; Yelon, Resnich \& Sleight, 1997) urging the adoption of transfer of training technology. The technology needs to be used to assist student teachers and teachers to transfer their education, training and experiences to the classroom. But few teachers and teacher educators are aware of the complexities of transfer theory and theimportance of knowing which transfer principles and strategies, in which context, with which group, are significant at any given point of time. There is a need for teacher educators to be skilled in the use of transfer of training approaches and the other significant inter-related issues of adult education, instructional design, educational change, and professional development approaches (McDonald, 2001).

A study undertaken by McDonald $(2001,2004)$ highlighted the value and importance of understanding transfer of training in an educational context. It noted that if knowledge, skills, strategies and approaches learnt in teacher workshop sessions are to be applied on the job, purposeful planning and use of transfer technology facilitates the teacher's use of the ideas in the classroom. This study undertaken in the Cook Islands identified the importance of 116 different specific activities, strategies and approaches (within the context of sound educational practice) that would facilitate "on-the-job" implementation 


\section{Training Inputs Training Outputs Conditions of Transfer}

\begin{tabular}{|c|c|c|}
\hline $\begin{array}{l}\text { Trainee Characteristics } \\
\text { - Ability } \\
\text { - Personality } \\
\text { - Motivation }\end{array}$ & & \\
\hline $\begin{array}{l}\text { Training Design } \\
\text { - Principles of leaning } \\
\text { - Sequencing } \\
\text { - Training content }\end{array}$ & $\begin{array}{l}\text { Learning } \\
\& \\
\text { Retention }\end{array}$ & $\begin{array}{c}\text { Generalization } \\
\& \\
\text { Maintenance }\end{array}$ \\
\hline $\begin{array}{l}\text { Work Environment } \\
\text { - Support } \\
\text { - Opportunity to use }\end{array}$ & & \\
\hline $\begin{array}{l}\text { KEY: } \\
\text { 1. Generalization of material } \\
\text { 3. Effect on training outcomes of } \\
\text { work environment } \\
\text { 5. Effect on transfer of work environment }\end{array}$ & \multicolumn{2}{|c|}{$\begin{array}{l}\text { 2. Maintenance of the material } \\
\text { 4. Effect on transfer of trainee characteristics } \\
\text { 6. Effect on transfer of training outcomes }\end{array}$} \\
\hline
\end{tabular}

Figure 1 Model of the Transfer Process (Baldwin \& Ford, 1988)

of workshop ideas in the teachers' classrooms. These were specific role (trainer, teacher, school and community support personnel) and time (before, during and after the workshop) strategies. The study highlighted, in particular, the importance of a training programme that acknowledged the active, learning involvement of teachers in a specific cultural context with provision of support for the teachers to implement new ideas in their classroom. It was a finding that noted the importance of a scaffolding of support via the "role x time" model to assist teachers toimplement change. It recognised the importance of "know-what" and "know-how" by means of a "know-with" support. This concept of "know-with" support expands upon Broudy's (1977) notion of "know with" which explains how cumulative knowledge experiences help an individual to perceive, interpret and judge situations. "Know-with support" adds an interactive element - the other's psychological and/or knowledge support assists the learner to access the necessary new knowledge and experiences. Support for change is thus a powerful mechanism for implementing ideas in the classroom (McDonald, 2001).

\section{Facilitating Teacher Development via Training}

Training can offer a valuable extra quality to education and experience in teacher development, providing a means of enhancing the links between the theory and the experience (as it does with many other professionals). Accordingly, there is an urgent need to reinvest in training in teacher development and to rid ourselves of the negative connotations associated with the concept. Training has proven to be very successful in education and continues to be so - there are indeed numerous models of training in education that can promote effective learning. Probably the most discussed and widely recognised approach is the five step method advocated by Joyce and Showers (1988). It suggests the following steps: theory, demonstration, practice, feedback, and coaching. An extension of this approach (North Central Regional Educational Laboratory, n.d.) incorporates a reflective component and a sharing element.

Training has proven to be invaluable over a wide range of skill areas, when it has been used. For example successful training has occurred in behavioural management (Allen \& Forman, 1984; Reid \& Parsons, 2000; Sawka, McCurdy \& Mannella, 2002), inquiry training and problem solving (Allan \& Blackston, 2003; Heung, 1999; Lombard, Konicek \& Schultz, 1985), interaction analysis and social skills training (Amidon \& Hough, 1967; Bullis, Walker \& Spragg, 2001), microteaching (MacLeod, 1987), protocols (Cruickshank \& Haefele, 1987), reflective teaching (Clift, Houston \& Pugach, 1990; Parsons \& Stephenson, 2005), simulation (Ferry et al., 2004; Cruickshank, 1990) and teacher effectiveness (Gage \& Needels, 1989; McDonald, 2001).

There have been numerous successful teacher training developments in New Zealand as well. One that has achieved world renown is its Reading Recovery programme, introduced in the early $1980 \mathrm{~s}$, and prescribing a very clear and detailed training programme for the specialist teachers involved. Kerslake (a Ministry of Education official) notes, "teachers are trained in the use of specific Reading Recovery teaching procedures, while working daily with a minimum of four children." (1999, p. 74) As a former New Zealand Department of Education psychologist, this writer can recall that two of the most efficient in-service training programmes that he participated in were the self-paced ERIC (Early Reading In-service Course) and LARIC (Later 
Reading In-service Course) training programmes of the late 1970s and early 1980s. It is interesting to note that recently the Resource Teachers (Literacy) have also undergone a "specific training programme at postgraduate or post-graduate certificate level, to ensure that all of the teachers who hold these positions are skilled in the latest strategies for literacy intervention" (New Zealand Government, February 8, 2001). It would seem that whenever practice is a priority, training is employed (at least in part).

Larson (2005), in a recent comment concerning pre-service teacher education in New Zealand, claimed that many new teachers were ill-prepared to meet the challenges of the classroom, and were unable to teach effectively, therefore limiting the learning outcomes of their students. Indeed a number of reports (e.g., Education Review Office, 2004) have detailed concerns about the performance of our young teachers in the schools. In discussing this concern, Larson identified a specific alternative private training provider that consistently produced teaching graduates that were highly skilled and sought-after for appointment. Anecdotal evidence, of course, needs to be treated with caution. Since this provider only accepted university graduates and the student teachers received considerably more experience in schools than normal, it is to be expected that the quality of their new teachers would be high. However, international literature (e.g., Wilson, Floden \& Ferrini-Mundy, 2002) indicates that understanding why teacher pre-service programmes are successful is a complex matter and doesn't simply relate to expert subject or pedagogy knowledge, field experiences or alternative training approaches. Given this, other factors can also be considered. Could it be, for example, that the two key players in this alternative teacher training programme are well qualified in working in a training role? Both have had extensive pre- and in-service training experience, both are experts in the area of instructional psychology and working with adults, and both have had extensive training/experience in managing learning of diverse student groups. Perhaps the key, however, is the carefully-managed learning programme provided for their student-teachers - experience and training go hand-in-hand and education tends to follow. Furthermore, they have a career history of understanding the relationship between education, training and experience, and provide ample feedback to link these three dimensions, although emphasis in the first instance is upon the "know-how" or the craft of teaching. Considerable time is given to the training in the form of guided practice and directive feedback.
Student placement in schools is frequent, but it is not simply being in the school that is important -it is the regular opportunities to relate the training to practice, the opportunity for anchored instruction and situated learning. The staff have clearly identified what is necessary for successful teaching, and train the student teachers to achieve this - a prerequisite for improving teacher education, according to Cruickshank and Metcalf (1994). It is indeed a demonstration of the close connection between education, training and experience.

Training should also have a significant role in the preparation of teacher educators. Most lecturers in the Schools of Education are appointed from a teaching position, and then required to educate young adults in professional education. Orientation or training for such positions has mostly been minimal, and yet "train the trainer" and adult learning programmes have existed for many year to meet adult trainers' needs. Sadly, the more general adult learning theory/practice and training literature would appear to have been essentially overlooked as a valuable source of assistance in the development of teachers (Imel, 2000; McDonald, 2004).

Equally important is the need to train the school-based staff who have principal responsibility for the on-going supervision of new teachers and the management responsible for on-going teacher development. The Education Review Office report (2004) clearly identified that one of the significant improvements required to raise the performance of new teachers in schools was to upgrade the support available to teachers within their schools. This could be readily accomplished with an emphasis upon training the helpers. Mentoring, an activity often associated with new teacher support, involves a relationship to assist with role development, but also embodies the ideas of collegiality and support (Field \& Field, 1994). Considerable literature exists highlighting the importance of mentoring, and of offering the appropriate type of support to young teachers (Carter \& Francis, 2001; Koki, 1997). Head, Reiman \& Thies-Sprinthall (1992) suggest that mentors should be involved in an ongoing training programme to improve their communication and active listening techniques, relationship conflict resolution and problem solving skills, effective teaching approaches, and understanding of models of supervision and coaching. The need for mentoring support is consistent with the organisational climate literature on transfer of training. One of the key determinants for effective transfer is the nature of the on-the-job support given to the trainee. Professionals work well when they 
"know-with" others. In New Zealand, tutor teachers supporting new teachers have little opportunity for training, and yet close, high-level skill development is required for the position. In addition, they need to learn the skills of collaboration to link with the young teacher and the other agencies involved in the teacher's on-going development. Research literature on supervision and mentoring of professionals, although still limited, is growing, but it clearly indicates that effective interaction in these contexts demands training (Milne \& James, 2004; Veenman \& Denessen, 2001). Teachers with the responsibility for their colleagues' professional development need the skills to work with adults, and need to adopt a variety of approaches that can facilitate improved sustained performance. Most do not have the qualifications for this role.

\section{Conclusion}

Training is not a panacea for the ills of teacher development, but does provide a context for teachers to understand theory and internalise experience. It is a framework that can provide meanings, structures for purposeful learning and avenues for attaining professional expertise. Indeed, training, theory and experience are interactive, and can be closely linked to knowing the what, how, when, why and with of teacher development. Teacher development will be forever thwarted unless training assumes a more prominent position.

On the mountains of truth you can never climb in vain: either you will reach a point higher up today, or you will be training your powers so that you will be able to climb higher tomorrow. (Friedrich Wilhelm Nietzsche)

\section{References}

Allan, S., \& Blackston, A. (2003). Training pre-service teachers in collaborative problem solving: An investigation of the impact on teacher and student behavior change in real-world settings. School Psychology Quarterly, 18(1), 22-51.

Allen, C., \& Forman, S. (1984). Efficacy of methods of training teachers in behavior modification. School Psychology Review, 13, 26-32.

Alton-Lee, A. (2003). Leading learning and teaching: Best evidence synthesis. Wellington: Ministry of Education.
Amidon, E., \& Hough, J. (Eds.). (1967). Interaction analysis, theory, research and application. Reading, PA: Addison-Wesley Publishing.

Baldwin, T. T., \& Ford, J. K. (1988). Transfer of training: A review and directions for future research. Personnel Psychology, 41, 63-105.

Berliner, D. (1994). Teacher expertise. In T. Husen, T. Postlethwaite (Eds.), The international encyclopaedia of education (Vol. 10, pp. 6020-6026). London: Pergamon.

Berliner, D. (2001). Learning about and learning from expert teachers. International Journal of Educational Research, 35, 463-482.

Billings, T. (1981). Knowing about and knowing how to do. Phi Delta Kappan, 62(8), 596-597, 610.

Blanchard, P \& Thacker, J. (2004). Effective training: Systems, strategies, and practices (2nd ed.). Upper Saddle River, NJ: Pearson Prentice Hall.

Brinkerhoff, R. O., \& Gill, S. J. (1994). The learning alliance: Systems thinking in human resource development. San Francisco: Jossey Bass.

Broad, M. L. (1997). Transfer concepts and research review. In M. L. Broad (Ed.), Transferring learning to the workplace (pp. 1-18). Alexandria, VA: American Society for Training and Development.

Broudy, H. (1977). Types of knowledge and purposes of education. In R. C. Anderson, R. J. Spiro, \& W. E. Montague (Eds.), Schooling and the acquisition of knowledge (pp. 1-17). Hillsdale, NJ: Lawrence Erlbaum.

Bullis, M., Walker, M., \& Spragg, J. (2001). A promise unfulfilled: Social skills training with at-risk and antisocial children and youth. Exceptionality, 9(1 \& 2), 67-90.

Carter, M. \& Francis, R. (2001). Mentoring and beginning teachers' workplace learning. Asia-Pacific Journal of Teacher Education, 29(3), 249-262.

Chew, E., \& McInnis-Bowers, C. (2003, September). Reflective thinking skills: Developing and accessing this management tool. Paper presented at the Association to Advance Collegiate Schools of Business International Continuous Process Improvement Symposium, St Louis, Missouri, USA.

Clift, R., Houston, W. R., \& Pugach, M. (1990). Encouraging reflective practice in education: An analysis of issues and programs. New York: Teachers College Press. 
Cochran-Smith, M. (2003). Teacher education's Bermuda triangle. Dichotomy, mythology and amnesia. Journal of Teacher Education, 54(4), 275-279.

Cochran-Smith, M. (2004). Ask a different question, get a different answer. The research base for teacher education. Journal of Teacher Education, 55(2), 111-115.

Cruickshank, D., \& Haefele, D. (1987). Teacher preparation via protocol materials. International Journal of Educational Research, 11(5), 543-554.

Cruickshank, D., \& Metcalf, K. (1994). Teacher education is not enough! Teacher Education Quarterly, 21(2), 115-128.

Cruickshank, D. (1990). Research that informs teaching and teacher preparation. Bloomington, IN: Phi Delta Kappa.

Dreyfus, H., \& Dreyfus, S. (1986). Mind over machine. New York: Free Press.

Education and Science Committee. (2004, November). Inquiry into teacher education. New Zealand House of Representatives, Wellington, New Zealand.

Education Review Office (ERO). (1998). The capable teacher. ERO Document \# 2. Wellington: ERO.

Education Review Office. (2004). The quality of year 2 beginning teachers. Wellington: ERO.

Eraut, M. (1994). Developing professional knowledge and competence. London: Falmer Press.

Farquharson, A. (1995). Teaching in practice. How professionals can work effectively with clients, patients, and colleagues. San Francisco: Jossey-Bass.

Fenstermacher, G., \& Richardson, V. (2000). On making determinations of quality in teaching. Washington, DC: Board on International Comparative Studies in Education of the National Academies/National Research Council.

Ferry, B., Kervin L., Cambourne, B., Turbill, J., Puglisi, S., Jonassen, D. \& Hedberg, J. (2004, December). Online classroom simulation: The next wave for pre-service teacher education? Paper presented at the conference of the Australasian Society for Computers in Learning in Tertiary Education, Perth, Australia.

Field, B., \& Field, T. (Eds.). (1994). Teachers as mentors: A practical guide. London: Falmer Press.
Fogarty, R., Perkins, D., \& Barrell, J. (1991a). How to teach for transfer. Highett, Victoria, Australia: Hawker Brownlow.

Gage, N. L., \& Needels, M. (1989). Process-product research on teaching: A review of criticism. Elementary School Journal, 89, 253-300.

Gallagher, M. (2000, June). Corporate universities, higher education and the future: Emerging policy issues. Paper presented at Australian Department of Education, Science and Training Corporate University Week, Sydney, Australia.

Glaser, R. (Ed.). (1962). Training research and education. Pittsburgh: University of Pittsburgh Press.

Glaser, R. (1996). Changing the agency for learning: Acquiring expert performance. In K. A. Ericsson (Ed.), The road to excellence: The acquisition of expert performance in the arts and sciences, sports and games (pp. 303-311). Mahwah, NJ: Erlbaum.

Gliessman, D. (1984). Changing teacher performance. In L. Katz \& J. Raths (Eds.), Advances in teacher education (Vol. 1), pp. 95-112. Norwood, NJ: ABLEX.

Haskell, R. E. (2001). Transfer of learning: Cognition, instruction and reasoning. San Diego, CA: Academic Press.

Hattie, J. (2003, October). Teachers make a difference. What is the research evidence? Paper presented to the conference of the Australian Council for Educational Research, Melbourne, Australia.

Head, F., Reiman, A., \& Thies-Sprinthall, L. (1992). The reality of mentoring: Complexity in its process and function. In T. Bey \& C. Holmes (Eds.), Mentoring: Contemporary principles and issues (pp. 5-24). Reston, VA: Association of Teacher Educators.

Heung, V. (1999, December). Problem-based learning for training teachers of students with behavioral disorders in Hong Kong. Paper presented at the First Asia Pacific Conference on Problem Based Learning. Hong Kong Convention and Exhibition Centre, Hong Kong.

Imel, S. (2000). Change: Connections to adult learning and education. ERIC Digest No. 221, Columbus, Ohio: ERIC Clearing House on Adult, Career and Vocational Education, Center on Education and Training for Employment, The Ohio State University.

Joyce, B., \& Showers, B. (1988). Student achievement through staff development. New York: Longman. 
Kerslake, J. (1999). Trends in Reading Recovery data between 1984 and 1998. The Research Bulletin, 10, 73-78.

Koki, S. (1997). The role of teacher mentoring in educational reform. PREL (Pacific Resources for Education and Learning) Briefing Paper. Honolulu, Hawaii. Retrieved May 1, 2005 from $<$ www.prel.org/products/products/role-mentor.pdf >

Kraiger, K. (2001). Preface. In K. Kraiger (Ed.), Creating, implementing, and managing effective training and development. San Francisco, CA: Jossey-Bass.

Kurtts, S., \& Levin, B. (2000). Using peer coaching with pre-service teachers to develop reflective practice and collegial support. Teaching Education, 11(3), 297-310.

Larson, V. (2005, February) Teacher, teacher, learning right? North and South, 227, 40-51.

Lombard, A., Konicek, R., \& Schultz, K. (1985). Description and evaluation of an in-service model for implementation of a learning cycle approach in the secondary science classroom. Science Education, 69, 491-500.

McDonald, B. L. (2001). Transfer of training in a cultural context. A Cook Islands study. Unpublished PhD thesis, Victoria University of Wellington.

McDonald, B. (2004, May). Akarongo kite Reo o te au Puapii: Listen to the voices of the teachers. Paper presented to the Pacific Association of Teacher Educators' Conference, Apia, Samoa.

McDonald, B. (2005). Training impact: Maximising aid projects. In K. Sanga, C. Chu, C. Hall, \& L. Crowl(Eds.), Re-thinking aid relationships in Pacific education (pp. 143 - 160). Wellington: Victoria University of Wellington, He Parekereke, Institute for Research and Development in Maori and Pacific Education, and University of South Pacific, Institute of Education, Suva.

Milne, D., \& James, I. (2002). The observed impact of training on competence in clinical supervision. British Journal of Clinical Psychology, 41, 55-72.

Munby, H., \& Russell, T. (1996). Theory follows practice in learning to teach and in research on teaching. Paper presented at 1996 annual meeting of the American Educational Research Association, New York.
New Zealand Government. (2001, February 8). Resource teachers: Literacy. Press release, retrieved June 12, 2005 from <www.scoop.co.nz/stones/PA0102/S00098.htm>

North Central Regional Educational Laboratory. (n.d.). Five phases of professional development. Retrieved on April 23, 2005 from <www.ncrel.org/sdrs/areas/issues/educatrs/profdevl/pd2fiph>

Organisation for Economic Cooperation and Development. (2000). Knowledge management in the learning society: Education and skills. Paris: OECD.

Parsons, M., \& Stephenson, M. (2005). Developing reflective practice in student teachers: collaboration and critical partnerships. Teachers and Teaching: Theory and Practice, 11(1), 95-116.

Perkins, D., Barell, J., \& Fogarty, R. (1989). Teaching for transfer. Palatine, IL: Skylight Publishing.

Reid, M., \& Barrington, H. (1999). Training interventions: Managing employee development (6th ed.). London: Institute of Personnel and Development.

Reid, D. H., \& Parsons, M. B. (2000). Organizational behavior management in human service settings. In J. Austin \& J. E. Carr (Eds.), Handbook of applied behavior analysis (pp. 275-294). Reno, NV: Context Press.

Rhodes, C., \& Beneicke, S. (2003). Professional development support for poorly performing teachers: Challenges and opportunities for school managers in addressing teacher learning needs. Journal of In-Service Education, 29(1), 123-140.

Robertson, E. (1987). Teaching and related activities. In M. J. Dunkin (Ed.), International encyclopedia of teaching and teacher education (pp. 15-18). Oxford: Pergamon Press.

Sawka, K., McCurdy, B., \& Mannella, M. (2002). Strengthening emotional support services: An empirically based model for training teachers of students with behavior disorders. Journal of Emotional and Behavioral Disorders, 10(4), 223-232.

Schön, D. (1987). Educating the reflective practitioner. San Francisco: Jossey Bass.

Thiessen. D. (2000). Developing knowledge for preparing teachers: Redefining the role of schools of education. Educational Policy, 14, 129-144. 
Veenman, S., \& Denessen, E. (2001). The coaching of teachers: Results of five training studies. Educational Research and Evaluation, 7(4), 385-417.

Wilson, S., \& Floden, R. (2003). Creating effective teachers: Concise answers for hard questions. Washington, DC: American Association of Colleges for Teacher Education.

Wilson, S., Floden, R., \& Ferrini-Mundy, J. (2002). Teacher preparation research: An insider's view from the outside. Journal of Teacher Education, 53(3), 190-204.

Yelon, S., Reznich, C., \& Sleight, D. (1997). Performance Improvement Quarterly, 10(2), 134-155.

\section{The author}

Lex McDonald is a senior lecturer in the School of Educational Studies,

Victoria University of Wellington. He is a psychologist with particular interests in the area of training and teacher education. Lex is currently co-writing a book on transfer of training and undertaking research on young teachers' perceptions of the transfer process. 